Res. Popul. Ecol. (1987) 29, 27-44.

(C) by the Society of Population Ecology

\title{
PARENTAL GARE AND EGG SIZE IN SALAMANDERS: AN EXAMINATION OF THE SAFE HARBOR HYPOTHESIS
}

\author{
Ronald A. NussBaum \\ Museum of Zoology and Department of Biology, The University of Michigan, \\ Ann Arbor, Michigan 48109-1079, U.S.A.
}

\section{INTRODUCTION}

One technique for the study of life history phenomena is to search for correlations among life history traits across populations or species and to formulate testable hypotheses that might explain the coevolution of the traits, bearing in mind that correlation does not necessarily reflect cause-and-effect. One well-known correlation is that between the presence or absence of parental care and propagule size in many invertebrates and coldblooded vertebrates. In these groups, parental care is generally restricted to the care of embryos from the time the eggs are deposited until the hatchlings begin to feed. Many species that lack parental care have relatively small eggs, and many species with parental care have relatively large eggs. Numerous authors (e.g., Breder, 1935; Cadwallader, 1976; Gurtis, 1938; Kuramoto, 1978; Salthe and Duellman, 1973; Shine, 1978; Svärdson, 1949; reviewed by NussBaum, 1985) argued that parental care is a prerequisite for the evolution of large eggs, and SHINe (1978) proposed an explanation for this relationship which he named the "safe harbor" hypothesis. Here, I examine the assumptions of the safe harbor hypothesis, test the ability of the safe harbor hypothesis to explain the correlation of parental care and egg size in one group of cold-blooded vertebrates, salamanders (Amphibia: Caudata), and propose an alternative explanation for the correlation between egg size and parental care in this group.

\section{The Safe Harbor Hypothesis}

In formulating the safe harbor hypothesis, ShINe (1978) started with the assumption that parental care had already evolved. He did not address the issue of the origin or loss of parental care. He further assumed that parental care, because it is so consistently present in many unrelated groups with relatively large propagules, in some way is responsible for the evolution of large propagules: "My aim...is to identify the critical variable that has been changed by parental care, and has thence influenced propagule size." (SHine, 1978: 419).

The safe harbor hypothesis is based on the suggestion of WILLIAMS, (1966) that natural selection will favor shortening of life history stages that have very low survivorship. SHINe (1978) argued that after parental care has evolved, survivorship of the protected 
embryos will have increased to the extent that the embryo stage is the safest harbor, compared to the subsequent juvenile stage, which does not benefit from parental protection. Invoking Williams' suggestion, Shine argued that natural selection now favors shortening of the high risk juvenile period, and that this can be done by prolonging the embryonic period. The embryonic period is prolonged by increasing egg size (at the cost of reduced fecundity). VANGE (1973a, b) formulated a similar model, which also depends on an inverse relationship between the duration of the embryonic and juvenile periods.

There are several assumptions of the safe harbor hypothesis that need to be examined. The first is Wirliams' (1966) idea that natural selection will reduce the duration of high risk stages. While this may happen, there are alternative solutions such as selection for protective devices, including parental care, to increase the survival rate of high risk stages.

A second assumption is that parental care will increase the survivorship of the embryonic stage to the extent that the juvenile stage is at relatively higher risk. There seems to be no reason why this generally should be true. Juvenile survivorship could conceivably be much higher than embryo survivorship, with or without parental protection of embryos. In fact this assumption is illogical when it is coupled with the assumption that egg size will increase under the influence of parental care. Any significant increase in egg size will increase the duration of the embryonic period (see below for salamanders), and hence total mortality accrued as embryos will increase regardless of whether or not parental care is provided. Therefore, even if parental care of embryos causes the juvenile stage to be at greater risk, as argued by SHINE (1978), unless the efficacy of parental care increases with increasing egg size, any increase in egg size among individuals with parental care will actually decrease the difference in "risk" of being an embryo or a juvenile.

A third assumption, the converse of the second, is that "In the species without parental care, propagule survivorship is likely to be lower (per unit time) than is the survivorship rate of free-living juveniles'" (Shrne, 1978: 419). Again, while this may be true, it is not necessarily so.

The fourth and most critical assumption of the safe harbor hypothesis is that an increase in egg size reduces the duration of the relatively high risk juvenile period. I can think of no a priori reason why a larger hatchling should necessarily result in a shortened larval period. The length of the juvenile period is likely to be modified independently of egg size and hatchling size. Among many frogs and salamanders, the duration of the larval period varies considerably from year to year and between individuals in the same population depending on immediate ecological conditions, regardless of hatching size. In the salamander family Ambystomatidae, species with small eggs tend to have short larval periods, and species with large eggs have relatively long larval periods (NussBaum, et al., 1983), the opposite of what would be predicted by assumption four of the safe harbor hypotheses. Within some species of frogs (LICHT, 1975a) and salamanders (ANDERson, 1967), hatchling size (and egg size) hardly varies geographically, but the larval period may vary by a factor of two or more, again contrary to assumption four. 
STRATHMANN (1977) identified similar cases among marine invertebrates in which there is no relationship between egg size and the duration of the pelagic larval stage. Advocates of the safe harbor hypothesis may choose to argue that it is not the entire juvenile stage that is shortened by increased egg size, but only some critical, high risk, segment of it.

Because of the economic principle of allocation of limited resources, larger propagules can be produced only at the cost of lower fecundity. Therefore, larger propagules cannot be advantageous unless they contribute significantly to increased survivorship of the propagule stage itself, or to increased survivorship of one or more subsequent life history stages. Increased propagule size alone is not likely to increase propagule survivorship. Because of the attendant increased embryonic period, the opposite is expected. Larger propagules could increase the survivorship of subsequent juvenile stages by decreasing the duration of the period at risk (safe harbor hypothesis), by increasing the survival rate of juveniles, or both. Because the total mortality accrued to a given life history stage is the product of the mortality rate and the duration of the stage, selection will always minimize both within the constraints of the system. Therefore, the safe harbor hypothesis may be more-or-less correct, depending on the circumstances. But, for some groups of organisms, the safe harbor hypothesis is unsatisfactory because it lacks explanatory power and is at least partly falsified by the evidence. It cannot explain the obvious correlation between propagule size and habitat that often exists, and, at least for salamanders, there are exceptional cases that contradict the safe harbor hypothesis.

\section{An Alternative Hypothesis}

Contrary to the safe harbor hypothesis, I argue that the selective advantage of larger eggs most often lies in the production of superior (larger) offspring that are better able to survive in certain environments than are smaller offspring. One cost of producing larger propagules is a longer embryonic period (see below for salamanders) and a resultant greater total mortality of embryos. Selection for larger propagules should, therefore, intensify selection for adaptations that reduce the rate of embryonic mortality, including protective devices such as toxins, hard embryonic coats, propagule hiding, and parental protection. I argue, then, that parental care is not necessarily the umbrella under which propagule size will increase inexorably, but, rather, that parental care may evolve as a consequence of selection for increased propagule (offspring) size.

\section{SALAMANDER Reproduction}

\section{General Considerations}

Several relevant reviews of salamander breeding biology have been published, the seminal papers being those of DunN (1923) and NoBle (1927). These authors demonstrated that there are three reproductive modes among salamanders: (1) small-egged pond (lentic) breeders, (2) large-egged stream (lotic) breeders, and (3) large-egged 
terrestrial breeders. These reproductive types were referred to as Modes I, II, and III by SALthe (1969). Modes I and II are characterized further by having indirect development with an aquatic larval stage and Mode III by having direct development in which the eggs hatch directly into terrestrial juveniles. Mode III salamanders belong to a single family (Plethodontidae), the members of which are all either Mode II or Mode III salamanders, with minor aberrations. DuNN (1926) contended that the ancestral plethodontid had Mode II reproductive features and that Mode III plethodontids evolved from Mode II plethodontids in cool, montane environments. This contention has not been seriously challenged. A few species of Old World salamandrids are live-bearing and do not fit neatly into the three-part scheme outlined above.

Parental care in salamanders consists of embryo guarding in a hidden aquatic or terrestrial nest. Hatchlings depart the nest soon after hatching to fend for themselves. They are not accompanied by the parent. Either the male alone or the female alone cares. There are no known certain cases of biparental care (Nussbaum, 1985). With a few exceptions, to be discussed below, Mode I salamanders lack parental care, and Mode II and III species have parental care (Nussbaum, 1985). Mode III salamanders will not be considered further in this paper for the following reason. There is strong evidence that all Mode III species are descended from Mode II plethodontids. Therefore, parental care and large eggs may never have originated in a Mode III species, but rather was universally inherited from two or three ancestral Mode II species (see REgAL, 1966 and WAKE, 1966 for alternative plethodontid phylogenies).

Egg size and hatchling size

Across a sample of 37 species of salamanders (Table 1) the correlation between ovum diameter and total length of hatchlings is highly significant $(r=0.978, p<0.0001)$. Selection for large hatchlings in salamanders is, therefore, tantamount to selection for large egg size.

Egg size and embryonic period

Among 35 species of salamanders (Table 1), there is a highly significant correlation between the duration of the embryonic period (uncorrected for temperature) and egg size $(r=0.788, p<0.0001)$. Doubling the egg size more than triples the embryonic period. Therefore, selection for increased hatchling size among salamanders carries with it the cost of a longer embryonic period (hence greater total embryonic mortality), a cost which may be exacerbated by the greatly reduced fecundity associated with the production of larger eggs. As argued above, increased embryonic mortality can be countered only by the evolution of mechanisms such as embryo hiding and parental care that will reduce the rate of embryonic mortality.

Validity of interspecific comparisons

Some authors assert that evolutionary arguments based on interspecific correlations, 
Table 1. Developmental data for salamanders.

\begin{tabular}{|c|c|c|c|c|c|c|}
\hline & $\begin{array}{l}\text { Habitat } \\
\text { of } \\
\text { Hatchling }\end{array}$ & $\begin{array}{c}\text { Parental } \\
\text { care }\end{array}$ & $\begin{array}{l}\text { Ovum } \\
\text { diameter } \\
(\mathrm{mm})\end{array}$ & $\left.\begin{array}{c}\text { Initial } \\
\text { feeding } \\
\text { size } \\
\text { (mm total } \\
\text { length }\end{array}\right)$ & $\begin{array}{l}\text { Embryonic } \\
\text { period } \\
\text { (days) }\end{array}$ & Authorities \\
\hline \multicolumn{7}{|l|}{ Ambystomatidae } \\
\hline Ambystoma cingulatum & lentic & - & 2.3 & 15.5 & 29 & $\begin{array}{l}\text { ANDERSON and WILLIAMSON, } \\
1976\end{array}$ \\
\hline Ambystoma gracile & lentic & - & 2.0 & 15.0 & 62 & $\begin{array}{l}\text { BisHOP, 1943; Licht, 1975b; } \\
\text { BROWN, } 1976\end{array}$ \\
\hline $\begin{array}{l}\text { Ambystoma } \\
\text { jeffersonianum }\end{array}$ & lentic & - & 2.2 & 13.0 & 30 & BisHop, 1941 \\
\hline Ambystoma mabeei & lentic & - & 2.2 & 15.0 & - & HARDY, 1969 \\
\hline Ambystoma maculatum & lentic & - & 2.7 & 16.0 & 36 & BisHoP, 1941 \\
\hline Ambystoma opacum & lentic & + & 2.7 & 18.3 & 41 & Bishop, 1941 \\
\hline Ambystoma tigrinum & lentic & - & 3.0 & 17.0 & 35 & BISHOP, 1941 \\
\hline Dicamptodon copei & lotic & + & 5.5 & 34.0 & 240 & NussBaum, unpublished \\
\hline Dicamptodon ensatus. & lotic & + & 6.6 & 47.0 & 275 & NussBaum, 1969a, unpublished \\
\hline Rhyacosiredon rivularis & slow lotic & $?$ & 2.7 & 20.0 & 35 & BRANDON and Altig, 1973 \\
\hline Rhyacotriton olympicus & lotic & - & 4.2 & 25.0 & 300 & NussBaum, 1969b, unpublished \\
\hline \multicolumn{7}{|l|}{ Cryptobranchidae } \\
\hline Andrias japonicus & lotic & + & 5.5 & 36.0 & 115 & Kerbert, 1904; TAgo, 1929 \\
\hline $\begin{array}{l}\text { Cryptobranchus } \\
\text { alleganiensis }\end{array}$ & lotic & + & 6.0 & 37.0 & 162 & Sмгтн, 1907, 1912 \\
\hline \multicolumn{7}{|l|}{ Hynobiidae } \\
\hline Onychodactylus japonicus & lotic & $?$ & 5.0 & 35.0 & 150 & IWASAWA and KERA, 1980 \\
\hline \multicolumn{7}{|l|}{ Plethodontidae } \\
\hline Desmognathus fuscus & lotic & + & 3.0 & 19.0 & 116 & $\begin{array}{l}\text { TILLEY, 1968; ORR and } \\
\text { MAPLE, } 1978\end{array}$ \\
\hline Desmognathus monticola & lotic & + & 4.0 & 23.5 & 181 & $\begin{array}{l}\text { Tilley, 1968; ORR and } \\
\text { MAPLe, } 1978\end{array}$ \\
\hline $\begin{array}{r}\text { Desmognathus } \\
\text { ochrophaeus }\end{array}$ & lotic & + & 3.0 & 18.0 & 140 & $\begin{array}{l}\text { Bishop, 1941; TilleY, 1968, } \\
\text { 1970; ORR and MAPLE, } 1978\end{array}$ \\
\hline $\begin{array}{l}\text { Desmognathus } \\
\quad \text { quadramaculatus }\end{array}$ & lotic & + & 4.5 & 29.0 & 183 & $\begin{array}{l}\text { MARTOF, 1962; TILLEY, 1968; } \\
\text { ORR and MAPLE, } 1978\end{array}$ \\
\hline Eurycea bislineata & lotic & + & 2.7 & 17.0 & 70 & $\begin{array}{l}\text { Bishop, } 1941 ; \text { DuELLMAN and } \\
\text { WoOD, } 1954\end{array}$ \\
\hline Eurycea lucifuga & lotic & $?$ & 2.5 & 17.0 & 68 & $\begin{array}{l}\text { Hutchinson, 1956; GREEN et } \\
\text { al., } 1967\end{array}$ \\
\hline $\begin{array}{l}\text { Gyrinophilus } \\
\text { porphyriticus }\end{array}$ & lotic & + & 3.5 & 27.0 & - & Bisнop, 1941 \\
\hline Hemidactylium scutatum & lentic & - & 2.7 & 15.0 & 30 & Bishop, 1920 \\
\hline Pseudotriton ruber & lotic & $?$ & 3.3 & 25.0 & 150 & BRUCE, 1968 \\
\hline \multicolumn{7}{|l|}{ Proteidae } \\
\hline Necturus maculosus & lotic/lentic & + & 5.5 & 36.0 & 86 & BisноP, 1926 \\
\hline Proteus anguinus & $\begin{array}{c}\text { lotic } \\
\text { (subterranean) }\end{array}$ & n) & 4.0 & 31.0 & 180 & $\begin{array}{l}\text { VANDEL and BouILLON, 1959; } \\
\text { BRIEGLEB and SGHWARTZ- } \\
\text { KOPFF, 1961; THORN, } 1968\end{array}$ \\
\hline \multicolumn{7}{|l|}{ Salamandridae } \\
\hline Cynops pyrrhogaster & lentic & - & 2.0 & 14.3 & 42 & ANDERSON, 1943 \\
\hline Echinotriton andersoni & lentic & - & 3.1 & 20.0 & 33 & $\begin{array}{l}\text { UTSUNOMIYA and UTSUNOMTYA, } \\
1977\end{array}$ \\
\hline Euproctus asper & lotic & - & 3.0 & 20.0 & 100 & GAssER, 1964 \\
\hline
\end{tabular}




\begin{tabular}{|c|c|c|c|c|c|c|}
\hline $\begin{array}{l}\text { Notophthalmus } \\
\text { viridescens }\end{array}$ & lentic & - & 1.5 & 9.0 & 25 & PoPE, 1924; Bishop, 1941 \\
\hline Pleurodeles waltl & lentic & - & 1.7 & 12.6 & 20 & Gallien and Durocher, 1957 \\
\hline Taricha granulosa & lentic & - & 1.8 & 12.0 & 26 & Twitty, 1936; Connon, 1947 \\
\hline Taricha rivularis & slow lotic & - & 2.8 & 18.5 & 31 & TwITty, 1936; Connon, 1947 \\
\hline Taricha torosa & lentic & - & 2.3 & 14.5 & 25 & TwIrTy, 1936; ConNon, 1947 \\
\hline Triturus alpestris & lentic & - & 1.8 & 11.5 & 13 & KNIGHT, 1938 \\
\hline Triturus helveticus & lentic & - & 1.5 & 10.4 & 20 & GALLIEN and BidAud, 1959 \\
\hline Triturus vulgaris & lentic & - & 1.5 & 8.0 & 20 & $\begin{array}{l}\text { ThORN, 1968; BeLL, 1974; } \\
\text { BeLL and LAWTON, } 1975\end{array}$ \\
\hline Tylototriton verrucosus & lentic & - & 2.3 & 15.3 & 27 & FERRIER, 1974 \\
\hline
\end{tabular}

like those presented above, are invalid unless the correlations can be demonstrated within populations. KAPLAN (1980), for example, argued that because he could find no correlation between egg size and embryonic period within populations of salamanders, larger egg size does not necessarily result in disadvantageously longer embryonic periods. This may be true for the relatively small differences in egg size that can be observed within a population in a very brief time frame such as a single breeding season. But, evolutionarily significant variation is not likely to be observable (measureable) on such a tiny space-time scale as that studied by KaPLAN. I have argued elsewhere (NussBaum, 1985) that interspecific correlations may be better indicators of functional relationships than intraspecific correlations, at least when relatively large changes in character states are considered.

Egg size and larval habitat

Increased (or decreased) parental investment (per offspring) will evolve only if it results in a greater number of offspring surviving to maturity. The two major factors that effect offspring survival are predation and nutrition. In regard to the latter, the amount and quality of food available to offspring effects not only survivorship, but other fitness components such as rate of growth; size, age, and condition when metamorphosis and maturation occur; and the growth trajectory of adult animals among species with indeterminant growth. Offspring survival and growth-related fitness will be maximized by providing them with (1) maximal protection and (2) maximal food, constrained by other aspects of the life history such as the need in iteroparous species to invest in future offspring. Considering that protection and food provisioning are the most important factors effected by changes in parental investment, it is reasonable to ask: what are the differences in predators and food between lentic and lotic environments that are likely to lead to relatively higher parental investment among lotic-breeding salamanders?

In regard to predators, the possibility must be considered that the large hatchlings from the large eggs of lotic-breeding salamanders have been selected to better escape predation. If this postulate is true, then one would expect to find a greater number and diversity of appropriate predators in the lotic environment than in the lentic environment. Unfortunately, there are no reliable objective data available. However, my subjective 
experience (and that of others, e.g., ITô, 1980; WELCH, 1935) is that there are more, and more kinds of, predators in the lentic, compared to the lotic, environment. This is the opposite of what would be expected if relatively larger eggs in stream-breeding salamanders resulted from selection caused by higher predation on hatchlings.

There is an unequivocal and fundamental difference in the food available to hatchlings between the lentic and lotic environments, and I am led to the hypothesis that this difference is responsible for the egg size/parental care dichotomy between Modes I and II salamanders. The primary food available to the carnivorous, hatchling salamanders in the lentic environment is zooplankton, a source that is almost completely absent from lotic environments (Allen, 1920; Birge and Juday, 1922; Pennak, 1943). Spring blooms of zooplankton in temperate, lentic environments provide a superabundance of food in tiny packets at the time when hatchling salamanders appear. In temperate, lotic environments, the benthic invertebrates available as food to hatchlings are much larger and less dense than the zooplankton of lentic environments.

Salamander larvae have needle-like, grasping teeth and must ingest their prey whole. Therefore it is reasonable to assume that the upper limit of prey size is controlled by the size of the mouth opening of larvae (as it is in fishes, e.g., WERnER, 1974; chaetognaths, Pearre, 1980; and larvae of benthic invertebrates, Thorson, 1946), which is correlated with all measures of larval body size. Female salamanders should be selected to produce eggs that result in hatchlings of optimal size for exploiting the food resources of their environment. Therefore, one would expect small eggs (hatchlings) in the lentic environment because producing larger hatchlings will not increase the availability of food for the hatchlings in this plankton-rich environment. The most abundant food in streams is of much larger size, and relatively large hatchlings (eggs) are required to exploit it.

The feeding ecology of lentic- and lotic-adapted larval salamanders is as one would expect if the hypothesis developed here is correct. Hatchlings, and even older larvae, of 11 species of lentic-breeding salamanders in two familes and three genera eat zooplankton almost exclusively (Hamilton, 1940; Anderson, 1968; Avery, 1968; Dodson, 1970; Bell, 1975; Licht, 1975b; Petranka and Petranka, 1980; Branah and Altig, 1981). By contrast, hatchlings and older larvae of three species (in two genera) of streambreeding ambystomatid salamanders had no plankton and no plankton-size food in their stomachs (ANToneliI, et al., 1972; Nussbaum, 1985).

Other factors, such as lower temperatures and current, have been suggested as selective agents of larger eggs in streams. While some of these may contribute to selection for larger eggs, size of available food seems to be the most important factor (reviewed by Nussbaum, 1985).

In summary, I propose an alternative hypothesis (to the safe harbor hypothesis) to explain the correlation between large eggs and parental care that occurs among salamanders. I argue that the lack of plankton in lotic environments is the factor that selects for larger hatchlings via larger eggs in Mode II salamanders. Larger eggs are produced at the cost of decreased fecundity and longer embryonic periods. Placement of eggs in 
hidden nests and parental care resulted from selection to decrease embryonic mortality rates to compensate for greater total mortality enforced by the longer embryonic periods.

\section{Tests of the Hypotheses}

Like most theories in evolutionary ecology, the safe harbor and alternative hypotheses cannot be tested by simple experimentation. Instead, it is necessary to test the hypotheses indirectly by examining predictions of the hypotheses and looking for natural experiments. Often it is true that exceptional populations or species provide indirect tests of competing hypotheses in this field of study.

\section{Exceptional cases}

Ambystoma opacum of the eastern United States is exceptional in that it has lenticadapted larvae and parental care (NoBLE and BRADY, 1933). It is also the only species of its genus of about 28 species reported to have parental care. Females deposit eggs just before the arrival of autumn or winter rains in terrestrial nests hidden under logs or leaf litter in depressions. Females stay with the eggs until the depressions are filled with rain water and the nests are flooded. The eggs then hatch and the lentic-adapted larvae assume a normal aquatic life-style. According to the safe harbor hypothesis, the eggs of A. opacum should be relatively large because of the presence of parental care. But, the eggs of $A$. opacum are not larger than the eggs of other species of Ambystoma that lack parental care. The mean egg diameter for $A$. opacum is $2.7 \mathrm{~mm}$, and the range of diameters for 14 other species for which data are available is 2.0 to $3.0 \mathrm{~mm}$ (NussBaum, 1985). In A. opacum, parental care has not led to large egg size. Rather, egg and hatchling size conform to the pattern observed among other salamanders with lentic-adapted larvae, in accordance with the alternative hypothesis. It should be noted that hatchling $A$. opacum ( $<24 \mathrm{~h}$ old) feed exclusively on zooplankton, and larvae of all sizes feed heavily on zooplankton (Petranka and Petranka, 1980; Branch and Altig, 1981). Why then, has parental care evolved in A. opacum? One possible answer is that, although their eggs are small, the embryonic period is facultatively long. The embryos have a mechanism to delay hatching until the rains arrive, should rainfall be delayed beyond the normal developmental period (Noble and Brady, 1933; Petranka et al., 1982). In the laboratory, embryos with arrested development have been maintained without hatching for over one year (Noble and Brady, 1933; Bishop, 1941). Therefore, under some circumstances, the embryonic period of this small-egged species may be as long or longer than the embryonic period of some large-egged species, resulting in similar selection pressures for embryonic protection.

Euproctus (Salamandridae, Europe) and Rhyacotriton (Ambystomatidae, NW U.S.A.) are two unrelated genera, the species of which are adapted for breeding in lotic waters. Although the species of these genera have large eggs $(3.0-4.2 \mathrm{~mm}$ diameter) as do all lotic-breeding salamanders, three of the four species involved do not have parental care, 
contrary to the prediction of the safe harbor hypothesis. These three species provide protection for their large embryos in other ways. Two species of Euproctus (E. asper, $E$. platycephalus) hide eggs singly by burying them in sand or by placing them in crevices and spaces between stones in streams (Despax, 1923; Algher, 1981a). The spaces where the eggs are hidden are too small for access by predators and egg cannibals (DEsPAx, 1923). This is accomplished by a morphological adaptation that is unique among salamanders. The female cloaca is cone-shaped and serves as an ovipositor, much in the manner of the ovipositor of the fish, Rhodeus amarus, which uses its elongated cloaca to place eggs inside the mantle cavity of bivalve mollusks. Scattering of single eggs over and extended period by these two species of Euproctus is also a protective mechanism. Interestingly, the third species of Euproctus (E. montanus) does not scatter eggs, but places them together at one time on the undersurface of a stone in a stream. The female of this species does not have a conical, ovipositior-like cloaca, and the eggs are not placed in crevices. The relatively exposed and clumped embryos of $E$. montanus are guarded by the female throughout the embryonic period (Alcher, 1981b). Rhyacotriton olympicus hides eggs deep in narrow cracks in rocks (Nussbaum, 1969a). The small size of adult $R$. olympicus allows them to place eggs in sites that are inaccessible to all other aquatic vertebrates in the region where they occur, although egg cannibalism cannot be ruled out. The virtually inaccessible nests of $R$. olympicus may obviate the need for parental care in this species.

The circumstances of these exceptional cases are consonant with the argument that the large eggs of lotic-adapted salamanders were selected to produce large hatchlings; and that, contrary to the safe harbor hypothesis, parental care is a result of, and not a precondition of, the evolution of increased egg size.

In the cases of Euproctus (asper and platycephalus) and Rhyacotriton, it could be argued that egg hiding and scattering are forms of parental care and that the absence of embryo guarding in these salamanders, therefore, is not necessarily contrary to the safe harbor hypothesis. However, if Surnes's (1978) hypothesis is expanded or generalized from parental care restricted to embryo guarding to include any mechanism that increases embryonic survival, then considerable additional evidence from salamander biology weighs against the safe harbor hypothesis.

Egg scattering and hiding is a common feature of many salamandrids including pond- and stream-breeding species. As discussed above, the stream-breeding species of this group (Euproctus spp.) have large eggs as do all stream-breeding salamanders. Salamandrids of the genera Cynops, Notophthalmus and Triturus are pond-breeders that scatter their eggs singly and hide each egg by wrapping them in leaves of aquatic plants. The eggs of species of these latter genera are small like those of other pond-breeding salamanders (Table 1). Therefore, scattering and hiding of eggs among salamandrid species has not resulted uniformly in large eggs as would be expected according to the modified safe harbor hypothesis. Instead, large eggs are found only among the streambreeders and small eggs among the pond breeders in accordance with the food availability 
argument.

The modified safe harbor hypothesis would predict that eggs provisioned with virulent toxins, as are those of the salamandrid species of the genus Taricha (TwITTY, 1966; BRODIE et al., 1974), should be relatively large because of their immunity to predation. However, the eggs of these species are small and in the same size range of the eggs of other pond-breeders (Table 1). The species with the largest eggs, T. rivularis (see below), breeds in slow streams. Again, the food availability hypothesis, rather than the modified safe harbor hypothesis, is supported.

\section{Transitional cases}

Species that are transitional between lentic- and lotic-adapted reproductive modes provide additional "tests" of the two hypotheses. In western North America, newts (Salamandridae) of the genus Taricha are basically lentic breeders, but the most specialized (derived) of the three species, T. rivularis, breeds in slow-moving streams (RIEMER, 1958). Eggs of this species are attached to the undersurfaces of stones in streams and left unattended. Eggs of the two pond- and lake-breeders are deposited in exposed sites and are also unattended. Eggs of the two lentic species average 1.8 and $2.3 \mathrm{~mm}$ in diameter, whereas the eggs of the transitional $T$. rivularis average $2.8 \mathrm{~mm}$ (TwITTy, 1936). The embryos of $T$. rivularis require at least a week longer to develop than embryos of the other two species (Gonnon, 1947). These observations are inconsistent with the safe harbor hypothesis in that $T$. rivularis has relatively large eggs in the absence of parental care and consistent with the alternative hypothesis in that the species with the largest eggs and longest embryonic period breeds in semi-lotic to lotic habitats. The egg-hiding behavior of $T$. rivularis may be an evolutionary response to the prolonged embryonic period associated with the relatively large eggs.

\section{Disqussion}

Ever since LAck (1954), it has generally been understood that the evolution of reduced clutch size results from selection for increased parental investment (per offspring) and not for reduced clutch size, per se. It is also generally understood that parental investment includes expenditure both on propagule substance (yolk, endosperm, seed coat, etc.) and parental care (incubation, feeding nestlings, lactation, protection). Because large eggs and parental care are both manifestations of increased parental investment, their frequent co-occurence cannot be explained satisfactorily by assuming that the existence of one (parental care) will cause the evolution of the other (large eggs), as was done by proponents of the safe harbor hypothesis. Rather, it seems that one should ask: What are the environmental conditions that select for changes in parental investment, and how should the changes be manifested in groups with difference life history constraints?

Alternatively, it is possible to attempt to explain changes or differences in parental 
investment within the rubric of general concepts such as $\mathrm{r}$ and $\mathrm{K}$ theory. This is especially tempting because some features of Mode I reproduction of salamanders (numerous small eggs; no parental care) have been identified with r-selectedness, and features of Mode II reproduction (few large eggs; parental care) with K-selectedness (MAcArthur, 1962; MacArthur and Wrlson, 1967; Pianka, 1970, 1978).

In the recent past, the theory of $\mathrm{r}$ and $\mathrm{K}$ selection became a "panchreston" in the sense of HARDIN (1956), i.e., a facile explanation for almost all life history phenomena, in spite of warnings by some evolutionary ecologists (e.g., WiLbUR, et al., 1974; HrRshFIELD and Tinkle, 1975; Stearns, 1977; Itô, 1980; Parry, 1981) that the theory is oversimplified and has little explanatory power. GouLD's (1977) attempt to link r- and $\mathrm{K}$-selection with heterochrony is an example of such excesses. There was also the unfortunate tendency to use the reproductive traits of populations as evidence that a particular population is $\mathrm{r}$ - or K-selected. Such use of the theory of $\mathrm{r}$ and $\mathrm{K}$ selection is tautological. The explanatory power of the theory can be demonstrated only if the characteristics of the populations and their environments are viewed separately. It is usually difficult, if not impossible, to determine whether an environment is a $\mathrm{K}$ - or an $\mathrm{r}$ environment for a particular population (e.g., Nussbaum and TArt, 1977). Because each species of a community uses the environment differently, a single environment may be both a K-and an r-environment, and it requires considerable familiarity with the life history of a species to be able to make an intelligent guess as to the nature of the selective forces that shaped the life history. In the present case, one must ask whether the lotic habitat of Mode II salamanders is a K-environment or an r-environment relative to the lentic habitat of Mode I salamanders. This question probably cannot be answered definitively, but, considering that lotic environments are less productive and have fewer predators and competitors, most ecologists are likely to view lotic habitats as r-environments relative to lentic environments (e.g., ITô, 1970; ITô and IwASA, 1981). This is opposite to the prediction of $\mathrm{r}$ and $\mathrm{K}$ theory in regard to the evolved reproductive modes of lentic and lotic salamanders.

Neither the safe harbor hypothesis nor $\mathrm{r}$ and $\mathrm{K}$ theory, satisfactorily explains the relatively high parental investment in stream-breeding salamanders compared to pondbreeding salamanders. The alternative hypothesis offered above is in accord with, but was developed independently of, the more general theory of Yosiaki ITô (ITô, 1959, 1970, 1980; Irô and IwASA, 1981). ITô found that the predictions of $r$ and $K$ theory were not realized across a broad range of plants and animals, and he sought an alternative explanation for the evolution of the high- and low-fecundity strategies. His solution is rooted in Lack's Principle and will be referred to here as the "LAak-ITô Hypothesis."

ITô accepted Lack's ideas on the fundamental inversity of parental investment (per offspring) and fecundity and Lack's explanation for the evolution of reduced clutch size. He furthermore concluded that parental investment increases directly with the difficulty of obtaining food (sunlight in the case of some plants) for offspring. At first, ITô (1959, 1970) developed a concept of "relative oligotrophy" in which relatively high oligotrophy 
was correlated with the low fecundity/large egg/parental care strategy (K-strategy) and relatively low oligotrophy was correlated with the high fecundity/small egg/no parental care strategy (r-strategy). Later, ITô (1980) realized that the appellation "relative oligotrophy" was inappropriate because he did not really have productivity or standing crop in mind, but, rather, the form of productivity or the availability of food resources to offspring of different feeding capabilities. ITô (1980:46) summarized his concept thusly: "...following LAck's original idea faithfully, I would propose the concept of the highfecundity strategist versus the low-fecundity/parental protection strategist and assert that the common factor among all organisms in determining the selection between these two types is the procurability of food by the young." Irô (1980) marshalled considerable empirical support for this hypothesis, to which can be added the observations of this paper regarding salamanders.

Viewed from a different perspective, the Lack-ITo hypothesis states that parental investment will be evolutionarily adjusted to yield maximum efficiency of exploitation of the food available to offspring. Maximum efficiency, as used here, translates into maximum parental fitness, and not maximum offspring fitness, as explained by SмIтH and Fretwell (1974), Brockelman (1975) and others. It is always to the parents' advantage to produce small young that can forage for themselves where the environment will allow it. In environments where the frequency, size, quality, or distribution of food available to offspring is such that small, independent offspring cannot efficiently (in terms of parental fitness) harvest it, parental investment must be greater. Manifestations of increased parental investment in such cases might include (1) larger young; (2) hidden or protective nests; (3) parental protection; and (4) food provisioning, including lactation, carrying food to the young, depositing infertile nurse eggs, and the production of sterile offspring that feed and protect other offspring.

\section{Summary}

The safe harbor hypothesis includes the suggestion that parental care causes the embryonic stage to be the safest harbor, and, therefore, egg size will increase in populations with parental care to decrease the duration of subsequent, higher risk stages. Neither the safe harbor hypothesis nor $\mathbf{r}$ and $\mathbf{K}$ theory seem adequate to explain the correlation between egg size and the presence/absence of parental care among salamanders, a group in which there is a further correlation between the larval (hatchling) habitat and egg size/ parental care. Pond-breeding salamanders generally have small eggs and lack parental care, and stream-breeding salamanders generally have large eggs and parental care. I argue that the fundamental difference in the food available to hatchling salamanders between lentic (plankton-rich) and lotic (plankton-poor) environments selects for relatively lower parental investment in the lentic environment. From the standpoint of parental fitness, small (more numerous) hatchlings have a greater payoff where the available food is small and dense (zooplankton in lentic environments), and large hatchlings are selective- 
ly advantageous where the food is of large size and less dense (benthic invertebrates in lotic environments). Selection for larger hatchlings in lotic environments results in longer embryonic periods and, ceteris paribus, greater total embryonic mortality. Embryo hiding and guarding have evolved among lotic-breeding salamanders as compensatory mechanisms to reduce the rate of embryonic mortality. In this view, parental care is a consequence of selection for larger egg size and not an umbrella that allows egg size to increase, contrary to the safe harbor hypothesis.

The relationship between variance in parental investment and food available to offspring, developed here for salamanders, may be of general significance. Yosiaki ITô, a critic of $\mathrm{r}$ and $\mathrm{K}$ theory, independently arrived at a similar conclusion from a broader data base.

Acknowledgements: I thank Richard D. Alexander, Lawrence S. Blumer, Edmund D. Brodie, Jr., Peter K. Ducey, David L. Sakultz, and Mark Wilkinson for critical review of this paper.

\section{References}

ALCHER, M. (1981a) Reproduction en elevage de Euproctus platycephalus (Urodela, Salamandridae). Amphibia-Reptilia 2: 97-105.

ALcher, M. (1981b) Sur l'existence de soins parentaux chez Euproctus montanus (Urodela, Salamandridae). Amphibia-Reptilia 2: 189-194.

Allen, W. E. (1920) A quantitative and statistical study of the plankton of the San Joaquin River and its tributaries in and near Stockton, California, in 1913. Univ. Calif. Publ. Zool. 22: 1-292.

ANDERSON, J.D. (1967) A comparison of the life histories of coastal and montane populations of Ambystoma macrodactylum in California. Amer. Midl. Nat. 77: 323-355.

ANDERson, J. D. (1968) A comparison of the food habits of Ambystoma macrodactylum sigillatum, Ambystoma macrodactylum croceum, and Ambystoma tigrinum califoriense. Herpetologica 24: 273-284.

Anderson, J. D. and G. K. Wilutamson (1976) Terrestrial mode of reproduction in Ambystoma cingulatum. Herpetologica 32: 214-221.

Anderson, P. L. (1943) The normal development of Triturus pyrrhogaster. Anat. Rec. 86: 59-63.

Antonelit, A. L., R. A. Nussbaum and S. D. Smith (1972) Comparative food habits of four species of stream-dwelling vertebrates (Dicamptodon ensatus, D. copei, Cottus tenuis, Salmo gairdneri). Northwest Sci. 46: 277-289.

Avery, R. A. (1968) Food and feeding relations of three species of Triturus (Amphibia Urodela) during the aquatic phases. Oikos 19: 408-412.

BELL, G. (1974) The reduction of morphological variation in natural populations of smooth newt larvae. J. Anim. Ecol. 43: 115-128.

BeLL, G. (1975) The diet and dentition of smooth newt larvae (Triturus vulgaris). J. Zool. (London) 176: $411-424$.

BeLL, G. and J. H. LAwTon (1975) The ecology of the eggs and larvae of the smooth newt (Triturus vulgaris (LinN.)). J. Anim. Ecol. 44: 393-423.

Birge, E. A. and C. Juday. (1922) The inland lakes of Wisconsin. The plankton. I. Its quantity and chemical composition. Wis. Geal. Nat. Hist. Survey, Bull., Sci. ser 64: 1-222. 
Bishop, S. C. (1920) Notes on the habits and development of the four-toed salamander, Hemidactylitum scutatum (SchleGel). New York State Mus. Bull. 219: 251-282.

Bishop, S. C. (1926) Notes on the habits and development of the mudpuppy Necturus maculosus (RAfinesque). New York State Mus. Bull. 268: 5-61.

Bishop, S. C. (1941) The salamanders of New York. New York State Mus. Bull. 324: 1-365.

Brshop, S. C. (1943) Handbook of salamanders. Comstock, Ithaca.

Branch, L. C. and R. Altig (1981) Nocturnal stratification of three species of Ambystoma larvae. Copeia 1981: 870-873.

Brandon, R. A. and R. G. Altig (1973) Eggs and small larvae of two species of Rhyacosiredon. Herpetologica 29 : 349-351.

BREDER, C. M. (1935) The reproductive habits of the common catfish, Ameiurus nebulosus (LeSUEUR), with a discussion of their significance in ontogeny and phylogeny. Zoologica 19: 143-179.

Briegleb, W. and J. SchwartZkopff. (1961) Verhaltensweisen des Grottenolms (Proteus anguinus LaUr.) und das Problem des Fortplanzungsraumes. Naturwissenschaften 22: 1-3.

Brockelman, W. Y. (1975) Competition, the fitness of offspring, and optimal clutch size. Amer. Natur. 109: 677-699.

BRodie, E. D., Jr., J. L. Hensel, Jr. and J. A. Johnson (1974) Toxicity of the urodele amphibians Taricha, Notophthalmus, Cynops, and Paramesotriton (Salamandridae). Copeia 1974: 506-511.

Brown, H. A. (1976) The time-temperature relation of embryonic development in the northwestern salamander, Ambystoma gracile. Can. J. Zool. 54: 552-558.

BRUCE, R. C. (1968) Life history studies of the salamanders of the genus Pseudotriton (Caudata: Plethodontidae). Ph.D. Dissertation, Duke University.

CAdwallader, P. L. (1976) Breeding biology of a non-diadromous galaxiid, Galaxias vulgaris Stokell, in a New Zealand river. J. Fish. Biol. 8: 157-177.

Connon, F. E. (1947) A comparative study of the respiration of normal and hybrid Triturus embryos and larvae. J. Exp. Zool. $105:$ 1-24.

Curtis, B. (1938) The life story of the fish. D. Appleton-Century Co., New York.

Despax, R. (1923) Contribution a l'etude anatomique et biologique des batraciens urodeles, du groupe des euproctes et specialement de l'euprocte des Pyrenees Triton (Euproctus) asper Duges. Theses pour Docteur Sci. Nat. Toulouse, Ser. A, No. 929.

Dodson, S. I. (1970) Complementary feeding niches sustained by size-selective predation. Limnol. and Oceanog. 15: 131-137.

Duellman, W. E. and J. T. Wood (1954) Size and growth of the two-lines salamander, Eurycea bislineata rivicola. Copeia 1954: 92-96.

Dunv, E. R. (1923) The breeding habits of salamanders and their bearing on phylogeny. Copeia 115: $25-28$.

Dunn, E. R. (1926) Salamanders of the family Plethodontidae. Smith College, Fiftieth Anniversary Publ. Ser. Vol. 7.

FerRIER, V. (1974) Chronologie du developpement de l'amphibien urodele Tylotriton verrucosus Anderson (Salamandridae). Ann. d'Embryol. et de Morphogenese 7: 407-416.

Gallien, L. and O. Bidaud (1959) Table chronologique de developpement chez Triturus helveticus Raz. Bull. Soc. Zool. Fr. 84: 22-32.

Gallien, L. and M. Durocher (1957) Table chronologique du developpement chez Pleurodeles waltii MiсHAн. Bull. Biol. Fr. Belg. 91: 97-114.

GASSER, F. (1964) Observations sur les stades initiaux du developpement de l'urodele Pyreneen Euproctus 
asper. Bull. Soc. Zool. Fr. 89 : 423-428.

Gould, S. J. (1977) Ontogeny and phylogeny. Belknap Press, Harvard University, Cambridge.

Green, N. B., P. Brant, Jr., and B. Dowler (1967) Eurycea lucifuga in West Virginia: its distribution, ecology, and life history. Proc. W. Virginia Acad. Sci. 39: 297-304.

Hamilton, W. J., Jr. (1940) The feeding habits of larval newts with reference to availability and selection of food items. Ecology 21: 351-356.

Hardin, G. (1956) Meaninglessness of the word protoplasm. Sci. Monthly 82: 112-120.

HARDY, J. D., Jr. (1969) A summary of recent studies on the salamander, Ambystoma mabeei. Chesapeake Biol. Lab. Ref. No. 69-20: 1-3.

Hirschfield, M. F. and D. W. Tinkle (1975) Natural selection and the evolution of reproductive effort. Proc. Nat. Acad. Sci. 72: 2227-2231.

Hutchinson, V.H. (1956) Notes on the plethodontid salamanders, Eurycea lucifuga (RAFINESQUE) and Eurycea longicauda longicauda (Green). Occas. Paps. Natl. Speleol. Soc. 3: 1-24.

Iтô, Y. (1959) Comparative ecology. Iwanami, Tokyo (in Japanese).

ITô, Y. (1970) Groups and family bonds in animals in relation to their habitat. 389-415. In L. R. Aronson, E. Tobagh, D. S. Lehrman and J. S. Rosenblatt (eds) Development and evolution of behavior. W. H. Freeman and Co., San Francisco.

Iтô, Y. (1980) Comparative ecology. Second ed., trans. by J. KIKKawa. Cambridge University Press, Cambridge.

Itô, Y. and Y. Iwasa (1981) Evolution of litter size I. Conceptual reexamination. Res. Popul. Ecol. 23: 344-359.

IWASAWA, H. and Y. KERA (1980) Normal stages of development of the Japanese lungless salamander, Onychodactylus japonicus (HoutTuYN). Jap. J. Herpetol. 8: 73-89 (in Japanese).

KAPLAN, R. H. (1980) The implications of ovum size variability for offspring fitness and clutch size within several populations of salamanders (Ambystoma). Evolution 34: 51-64.

Kerbert, C. (1904) Zur Fortpflanzung von Megalobatrachus maximus SaHLegel (Cryptobranchus japonicus v.D. Hoeven). Zool. Anz. $27:$ 305-320.

Knight, F. G. E. (1938) Die Entwicklung von Triton alpestris bei verschiedenen Temperaturen, mit Normentafel. Wilhelm Roux's Archives 137: 461-473.

Kuramoto, M. (1978) Correlations of quantitative parameters of fecundity in amphibians. Evolution 32: $287-296$.

LACK, D. (1954) The evolution of reproductive rates. 143-156. In J. HuxLEY, A. C. HARDY and E. B. Ford (eds) Evolution as a process. Allen and Unwin, London.

Lichт, L. E. (1975a) Comparative life history features of the western spotted frog, Rana pretiosa, from low- and high-elevation populations. Can. J. Zool. 53: 1254-1257.

Lichr, L. E. (1975b) Growth and food of larval Ambystoma gracile from a lowland population in southwestern British Columbia. Can. J. Zool. 53: 1716-1722.

MacArthur, R. H. (1962) Some generalized theorems of natural selection. Proc. Natl. Acad. Sci. 48: 1893-1897.

MacArthur, R. H. and E. O. Wilson (1967) The thoery of island biogeography. Princeton University Press, Monographs in Pop. Biol. 1.

Martof, B. S. (1962) Some aspects of the life history and ecology of the salamander Leurognathus. Amer. Midl. Natur. 67: 1-35.

Noble, G. K. (1927) The value of life history data in the study of the evolution of the Amphibia. Ann. Now York Acad. Sci. 30: 31-128. 
Noble, G. K. and M. K. Brady (1933) Observations of the life history of the marbled salamander, Ambystoma opacum Gravenhorst. Zoologica 11: 89-132.

Nussbaum, R. A. (1969a) Nests and eggs of the Pacific giant salamander, Dicamptodon ensatus (Eschscholtz). Herpetologica 25 : 257-262.

Nussbaum, R. A. (1969b) A nest site of the Olympic salamander, Rhyacotriton olympicus (GaIGE). Herpetologica 25 : 277-278.

Nussbaum, R. A. (1985) The evolution of parental care in salamanders. Misc. Publ. Museum of Zoology, University of Michigan 169: 1-50.

Nussbaum, R. A. and C. K. TAIT (1977) Aspects of the life history and ecology of the Olympic salamander, Rhyacotriton olympicus (GAIGE). Amer. Midl. Natur. 98: 176-199.

Nussbaum, R. A., E. D. Brodie, Jr. and R. M. Storm (1983) Amphibians and reptiles of the Pacific Northwest. University of Idaho Press, Moscow.

ORR, L. P. and W. T. MAPLE (1978) Competition avoidance mechanisms in salamander larvae of the genus Desmognathus. Copeia 1978: 679-7685.

PArry, G. D. (1981) The meanings of r- and K-selection. Oecologia 48: 260-264.

Pearre, J. Jr. (1980) Feeding by Chaetognatha: the relation of prey size to predator size in several species. Mar. Ecol. Prog. Ser. 3: 125-134.

Pennak, R. W. (1943) Limnological variables in a Colorado mountain stream. Amer. Midl. Natur. 29: $186-199$.

Petranka, J. W. and J. G. Petranka (1980) Selected aspects of the larval ecology of the marbled salamander Ambystoma opacum in the southern portion of its range. Amer. Midl. Natur. 104: 352-363.

Petranka, J. W., J. J. Just and E. C. Crawroro (1982) Hatching of amphibian embryos: the physiological trigger. Science $217: 257-259$.

Pianka, E. R. (1970) On r- and K-selection. Amer. Natur. 104: 592-597.

Pianka, E. R. (1978) Evolutionary ecology. Harper, New York.

Pope, C. H. (1924) Notes on North Carolina salamanders with especial reference to the egg-laying habits of Leurognathus and Desmognathus. Amer. Mus. Novit. 153: 1-15.

REGAL, P.J. (1966) Feeding specializations and the classification of terrestrial salamanders. Evolution 20: $392-407$.

Riemer, W.J. (1958) Variation and systematic relationships within the salamander genus Taricha. Univ. Calif. Publ. Zool. 56: 301-390.

SAlthe, S. N. (1969) Reproductive modes and the number and sizes of ova in the urodeles. Amer. Midl. Nat. 81 : $467-490$.

SAlthe, S. N. and W. E. DuellmaN (1973) Quantitative constraints associated with reproductive mode in anurans. 229-249. In J. L. VIAL, (ed) Evolutionary biology of the anurans. Univ. Missouri Press, Columbia.

Shine, R. (1978) Propagule size and parental care: the "safe harbor" hypothesis. J. Theor. Biol. 75: 417-424.

Sмiтн, B. G. (1907) The life history and habits of Cryptobranchus allegheniensis. Biol. Bull. 13: 5-39.

SмIтH, B. G. (1912) The embryology of Cryptobranchus allegheniensis, including comparisons with some other vertebrates. J. Morphol. 23: 61-157.

Smith, C. S. and S. D. Fretwell (1974) The optimal balance between size and number of offspring. Amer. Natur. 108 : 499-506.

Stearns, S. C. (1977) The evolution of life history traits: a critique of the theory and a review of the data. Ann. Rev. Ecol. Syst. 8: 145-171. 
Strathmann, R. R. (1977) Egg size, larval development, and juvenile size in benthic marine invertebrates. Amer, Natur. 111 : 373-376.

SvÄrDson, G. (1949) Natural selection and egg number in fish. Institute of Freshwater Research, Fishery Board of Sweden. Rept. No. 29: 115-122.

TAGo, K. (1929) Notes on the habits and life history of Megalobatrachus japonicus. Xe Congress Internatl. Zool. Budapest 1 : 828-838.

Thorn, R. (1968) Les salamanders d'Europe, d'Asie, et d'Afrique du nord. Paul Lechevalier, Paris.

Thorson, G. (1946) Reproduction and larval development of Danish marine bottom invertebrates, with special reference to the planktonic larvae in the sound (Oresund). Medd. Komm. Danm. Fisk.--og Havunders., Ser. Plankton 4: 1-523.

Tilley, S. G. (1968) Size-fecundity relationships and their evolutionary implications in five desmognathine salamanders. Evolution 22: 806-816.

Tilley, S. G. (1970) Aspects of the reproductive ecology of Desmognathus ochrophaeus in the southern Appalachian Mountains. Ph.D. Thesis, Univ. Mich., Ann Arbor.

Twirty, V. C. (1936) Correlated genetic and embryological experiments on Triturus. I and II. J. Exp. Zool. 74: 239-302.

TwitTY, V. C. (1966) of scientists and salamanders. W. H. Freeman, San Francisco.

Utsunomiya, Y. and T. UtsunomiYa (1977) On the development of Tylototriton andersoni. J. Fac. Fish. Anim. Husb., Hiroshima Univ. 16: 65-76 (in Japanese).

VANCE, R. R. (1973a) On reproductive strategies in marine benthic invertebrates. Amer. Natur. 107: 339-352.

VANCE, R. R. (1973b) More on reproductive strategies in marine benthic invertebrates. Amer. Natur. 107: 353-361.

VANdel, A. and M. Bourllon (1959) La reproduction du Protee (Proteus anguinus Laurentr). $C . R$. Acad. Sci. Paris 248: 1267-1272.

WAKE, D. B. (1966) Comparative osteology and evolution of the lungless salamanders, family Plethodontidae. Mem. So. Calif. Acad. Sci. 4: 1-111.

WeLch, P. S. (1935) Limnology. McGraw-Hill Book Co., Inc., New York.

WERNER, E. A. (1974) The fish size, prey size, handling time relation in several sunfishes and some implications. J. Fish. Res. Bd. Can. 31: 1531-1536.

Wilbur, H. M., D. W. Tinkle and J. P. Collins (1974) Environmental certainty, trophic level, and resource availability in life history evolution. Amer. Natur. 108: 805-817.

Williams, G. C. (1966) Adaptation and natural selection: a critique of some current evolutionary thought. Princeton University Press, Princeton, N.J.

サンショウウオの親による子の保護と卵サイズ——“Safe Harbor”仮説の検討——

Ronald A. NussBaum

親が子の保護を行う個体群においては，卵期が最も安全な時期となる。そてで, “Safe Harbor”仮説は, 保護を伴なった嵧のサイズが大きいのは卵期以降のより告険の大きい期間を短縮するためであると主張す る。しかしながら，サンショウウオで見られる卵のサイズと親による子の保護の間にみられる相関関係を， “Safe Harbor" 仮説や r-K理論では充分に説明できないように思われる。このグループでは，ふ化幼生の生 息場所と卵の大きさ・親による子の保護の間にあ相関関係がみられる。池で繁殖するサンショウウオは，一 
般に小さな卵を産み親は子の保護を行わない。それに対して，溪流で繁殖するサンショウウオは一般に大き な卵を産み親は子の保護を行う。著者は，プランクトンの豊富な止水とプランクトンのそしい流水環境での サンショウウオのふ化幼生の利用可能な䬲資源の差異が，止水環境において親の子への投資が比較的小さい ことの進化的な原因になっているととを論じる。親の適応度という観点からみれば，止水環境における動物 プランクトンのように利用可能な䬣のサイズが小さくかつ密度が高い様な環境では，小さな多数のふ化幼生 を残す方がより多くの報酬を得るととが出来る。そして, 流水環境における底生の無膋椎動物のように慨の サイズが大きくかつ密度が低いような環境では，大きなふ化幼生の方が自然選択上有利である。流水環境に おける大きなふ化奻生への自然選択は，卵期間の延長を招き，他の条件が同じならば，卵期の総死亡獄を增 加させる。卵を隠す行動や親による子の保護は, 卵の死亡事を減少させるための補償機構として流水で繁殖 するサンショウウオの間で進化した。との観点では, “Safe Harbor” 仅説とは正反対に, 親による子の保護 は大卵への自然選択の結果であり，卵サイズを増加させるととを許す前提条件ではない。

こてで明らかにしてきた，親の子への投資量の変異と子にとっての利用可能な餤の間の関係は，サンショ ウウオだけでなくすっと一般的に重要な意味を持っているかも知れない。ITÔ $\mathrm{r} \cdot \mathrm{K}$ 理論を批判して，より 幅広い事例から，著者とは別個に同様な結論に達している。 